
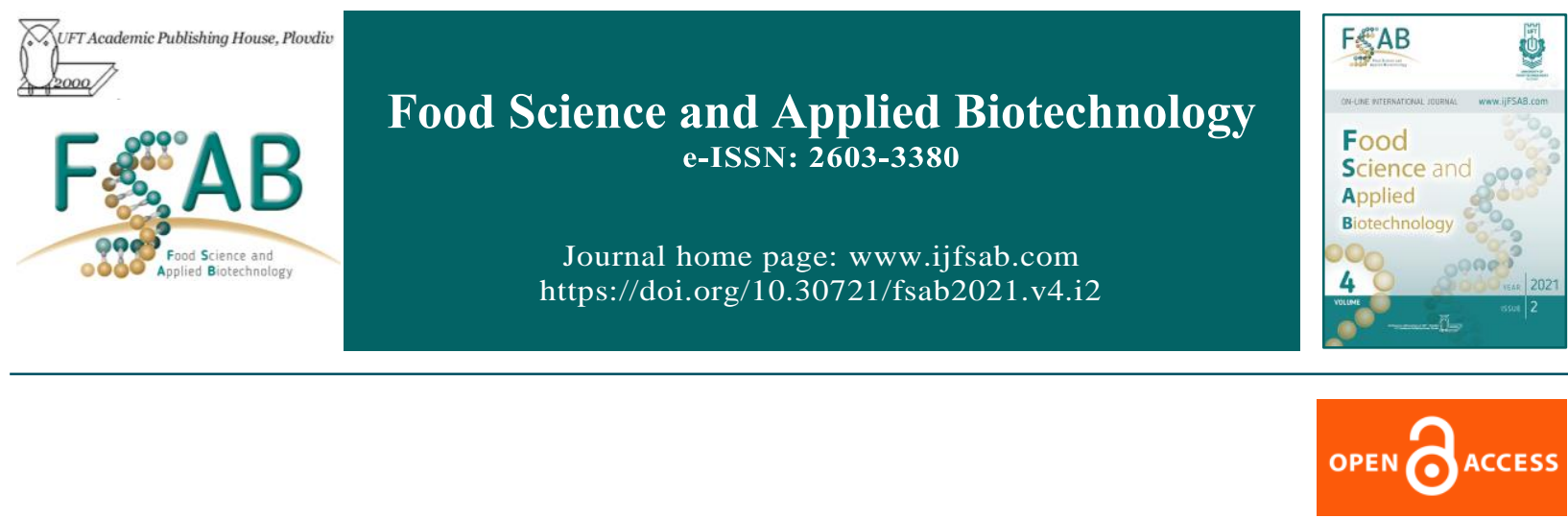

Research Article

\title{
Evaluating the flour properties under different levels of particle size distribution and fine bran content
}

Zeyad A. Ahmed ${ }^{1}$, Abeer S. Alhendi ${ }^{2}$, Mohammed S. Hussein ${ }^{1}$, Shaimaa A. Abed ${ }^{1}$, Rana T. Alsallami $^{2}$

${ }^{1}$ General Company of Grain Processing, Ministry of trade, Baghdad - Iraq

${ }^{2}$ Quality Control Department, Grain Board of Iraq, Ministry of Trade, Al Taji, Baghdad, Iraq.

\begin{abstract}
The main objective of this study was to determine the changes in the rheological characteristics of the flour produced by the industry mill Buhler AG 600 ton/day through adding big particles of flour, semolina, and fine bran (FB) to the produced flour. The study was conducted on mixed wheat grains $(80 \%$ Iraqi wheat and 20\% American Red wheat). After changing the directions of some pipes in the milling section, the flours were tested, and the effect of having bigger particles in the product was measured. The results showed that the flour extraction rate, moisture content, ash, and protein were increased as the flour particle size was increased. Farinograph results explained a clear effect of big particles and fine bran on increasing the water absorption, however, the dough stability was decreased mostly insignificantly. Extensiograph results showed that there was no big difference between the control flour and other produced flour. Therefore, the changes of the mill pipes could increase the flour extraction rate and reduce the pressure on the mill rolls without significant differences in the rheological properties of the produced flour.
\end{abstract}

Keywords: wheat flour, rheological properties, particle size, fine bran, industry mill

Abbreviations: F0 - fine flour, F1 - second line flour, Fp - packing flour, C1B1 - first two pipes, DiV second two pipes, FB - fine bran. $\mathrm{d}_{\mathrm{gw}}-$ The geometric mean diameter, $\mathrm{S}_{\mathrm{gw}}$ - the geometric standard deviation.

${ }^{\square}$ Corresponding author: Abeer S. Alhendi, Quality Control Department, Grain Board of Iraq, Ministry of Trade, Al Taji, Baghdad, Iraq , tel +9647823044190; Email:aalhendi@ufl.edu

Article history:

Received 23 June 2021

Reviewed 22 July 2021

Accepted 7 September 2021

Available on-line 10 October 2021

https://doi.org/10.30721/fsab2021.v4.i2.148 (C) 2021 The Authors. UFT Academic publishing house, Plovdiv 


\section{Introduction}

Grinding the wheat is one of the oldest methods of food processing recognized by mankind. Wheat flour had been the main source of protein for human beings since the dawn of agriculture (Krasileva et al. 2017). The highest percentage of protein content is found in the sub-aleurone region of wheat endosperm (Edwards et al. 2007). The flour with a low protein content is used mainly to produce cakes and biscuits, but high protein flour is used for bakery products (Faměra et al. 2004). Besides, bread volume, crumb formation, and gas retention depend to a great extent on gluten quality, protein content, and gluten development during dough mixing (Al-Dmoor 2013). In an investigation into the protein, Anjum et al. (2007) illustrated that gluten was the main protein of wheat flour, mostly responsible for determining dough elasticity and positively affected the high bread-making quality. Wieser et al. (2014) suggested that the gluten proteins were defined as it is storage proteins and created only in the starchy endosperm of the grains; additionally, they represented about $70-80 \%$ of total grain proteins. The gluten content of grain affects dough viscosity and extensibility, as well as its cohesiveness and elasticity (Joye et al. 2009). The dough flexibility and its ability to keep consistency and ensure its form not to split down during the vertical backing is a crucial topic in Iraqis traditional bread making, and it is a serious key value of the good bread backing.

Many techniques are used now to verify the flour particle size distribution, including sieve analysis, sedimentation, colter counter, microscopy, laser diffraction, and near-infrared reflectance spectroscopy (Hareland 1994). Generally, the typical particle size of the ground wheat endosperm (the main ingredient of the straight - standard flour) is less than $150 \mu \mathrm{m}$, and a higher percentage of bran particles are generally larger than $500 \mu \mathrm{m}$, before the advance fine milling process. Following the extra-fine grinding of bran particles in the mills, the average bran particle sizes might be reduced to $90-$ $440 \mu \mathrm{m}$ (Steglich et al. 2015). Wheat bran particle size is a serious component in the whole wheat milling, because of its significant effect on dough specification and quality of final products, like breads, noodles, cakes, and pasta (Wang et al. 2016).
Wheat flour is the final product of the wheat milling procedure and is defined as a heterogeneous combination of particles of diverse shapes and densities (Sonaye and Baxi 2012). Flour is the corner stone of many culinary dishes. It is used as the main ingredient in baked goods. In Iraq flour is used usually to be backed onto the inside vertical flat of the Iraqi classic oven producing Iraqi traditional bread named locally (Tannory), which is essentially needed to have a good gluten net to ensure keeping its volume and shape through the vertical backing operation. For the Iraqi ministry of trade, it is very important to deliver the flour (which is produced by Iraqi mills) to Iraqis people with steady specifications and with enough gluten to ensure the ability to back the flour with the Iraqi traditional vertical way which requires a specific quantity and quality of the gluten content, In addition, the particle size distribution of the flour have to have a level of softness that only $5 \%$ of its particles should stay on sieve $355 \mu \mathrm{m}$. Therefore, in Iraqi flour markets, it is necessary to study the effect of using flour produced with a range of particle size that $<355 \mu \mathrm{m}$ and at least $40 \%$ of flour passed through sieve $132 \mu \mathrm{m}$ with a maximum level of ash content have to be less than $1 \%$. (37 Iraqi limits standard).

The aim of this study was to determine the effect of producing flour with bigger particles on the production line to define the changes in the flour and dough properties. In addition to studying the effect of the fine bran on the flour rheological properties. And finally to take a good decision about applying the best experiment changes in the mill in order to enhance the production.

\section{Materials and Methods}

\section{The mill.}

The mill used in the study was Buhler AG 600 ton/day (Gupfenstrasses, Uzwil, Switzerland) located in Baghdad and belongs to the Iraqi ministry of trade - General Company of Grain Processing.

\section{Sample preparation.}

The investigations were conducted on mixed wheat cultivars (80\% Iraqi wheat harvested in 2019 and $20 \%$ American Red wheat imported in 2019). Wheat grains were received from the main stores in Baghdad in June 2019 and the raw wheat was 
subjected to screening, magnetic, dry stoner, and air cleaning machines. The mixed wheat was cleaned and moisturized to $16.5 \%$ in the mill cleaning section. The grain initial moisture content was defined automatically before the dumping machine and added enough amount of water to get the ideal wheat moisture content for grinding.

\section{Milling operation and changes taken.}

The flour produced in the mill consisted of two lines, the first line is designed for collecting the fine flour (F0) and the second line (F1) is designed for collecting the coarser particles of flour and the two types of flour are mixed for ratio 1:1 to get the final form of packing flour (Fp). The (F0) product has a scale at the end before it leaves the milling section and $(\mathrm{F} 1)$ has a different scale for the same purpose. On the tenth of July 2019, the experiment has been carried out when the mill was operating normally with a production rate of 15 tons/h, and the flour was produced under a stable extraction rate. The mixed flour of (F0) and (F1) before the changes were observed as a control. The various changes for the direction of the chosen pipes in the milling section were eliminated before, to shorten the flour producing operation and move the destination of specific particles of ground grains that moved out from the plan sifter (third floor) which are designed to go for further grinding, and get them instead to the flour production conveyer (F0) and (F1). The first two pipes (C1B1) were responsible for moving the ground materials with size $>280 \mu \mathrm{m}$ and $<$ $500 \mu \mathrm{m}$ from the plan sifter on the third floor to the rolling mill on the first floor. The second tow pipes (DiV) were responsible for moving the ground materials with a size $<280 \mu \mathrm{m}$ from the plan sifter on the third floor to the rolling mill on the first floor. The third pipe was responsible for moving the fine bran (FB) (which is isolated from the grain parts in the last grinding level) to the bran production line or the flour production line (through a bypass). The treatments of the experiment were Flour produced in the mill (Control), control + C1B1 (T1), control + DiV (T2), Control + C1B1 + DiV (T3), Control + FB (T4), and Control + C1B1 + DiV + FB (T5). The $2 \mathrm{Kg}$ flour samples were taken in duplicate before the treatments and after moving the pipes (T1, T2, $\mathrm{T} 3, \mathrm{~T} 4, \mathrm{~T} 5)$ in the milling section.

\section{Particle size analysis.}

The particle size distribution that represents Fp before and after the changes was calculated by sieving operation, the samples of flour in the bags were mixed carefully before $100 \mathrm{~g}$ of flour from each sample were subjected to the analysis of particle size distribution using the sieve shaker AS 200 (Retsch GmbH, Haan, Germany). The five sieves used in the experiment were put in descending order from top to bottom depending on the mesh size $500 \mu \mathrm{m}, 355 \mu \mathrm{m}, 250 \mu \mathrm{m}, 180 \mu \mathrm{m}$, and $132 \mu \mathrm{m}$ followed by gathering pan. Every 100 $\mathrm{g}$ of the flour samples were individually shaken in the machine for $5 \mathrm{~min}$ and the weight of the materials on each sieve were recorded by the laboratory scale (Precisa XB-4200C, 4802 Glenwood Rd. Brooklyn, NY 11234, US) in addition to the finest flour in the pan. The particle size distribution of each treatment was indicated by the schedule representing the quantity of the six size classes of the flour particles, which were $\geq 500 \mu \mathrm{m}$, $<500 \mu \mathrm{m}$ and $\geq 355 \mu \mathrm{m},<355 \mu \mathrm{m}$ and $\geq 250 \mu \mathrm{m}$, $<250 \mu \mathrm{m}$ and $\geq 180 \mu \mathrm{m},<180 \mu \mathrm{m}$ and $\geq 132 \mu \mathrm{m}$, and $<132 \mu \mathrm{m}$. The geometric mean diameter $\left(\mathrm{d}_{\mathrm{gw}}\right)$ and the geometric standard deviation $\left(\mathrm{S}_{\mathrm{gw}}\right)$ of the flour treatment were calcualted depending on Wilcox et al. (1970) following the equations:

$\mathrm{d}_{\mathrm{gw}}=\log ^{-1}\left[\frac{\sum(W i \log d i)}{\sum W i}\right]$

$\mathrm{S}_{\mathrm{gW}}=\log ^{-1}\left[\frac{\sum W i(\log d i-\log d g w) 2}{\sum W i}\right]$

where $\mathrm{Wi}=$ weight of flour fraction on the sieve and $\mathrm{di}=$ diameter of sieve.

\section{Chemical and physical tests of flour.}

The most commonly applied method for testing moisture in flours involves the use of an air oven AACC (44-10), in addition to the test of ash AACC (08-01), falling no AACC (56-81), protein content AACC (46-30), gluten and gluten index AACC (3812).

\section{Rheological characteristics.}

To determine the dough properties, Farinograph and Extensograph instruments were used, based on methods ICC (115/1) and AACC (54-10) respectively. 


\section{Statistical analysis.}

The effect of changing the particle size of the flour and adding fine bran on the flour properties and dough rheological tests was determined with SPSS software (IPM SPSS version 23Armonk, NC, U.S.A.) using One-way analysis of variance (ANOVA). The significance of differences was tested using the LSD test $(\mathrm{P} \leq 0.05)$.

\section{Results and Discussion}

The impact of mixing the Control flour with different streams of ground material is illustrated in Table 1. The highest particle weight (7.2 gm, 6.6 gm, $6.55 \mathrm{gm})$ that above $355 \mu \mathrm{m}$ and $500 \mu \mathrm{m}$ were recorded with $\mathrm{T} 1, \mathrm{~T} 3$, T5 respectively. Also the geometric mean diameter of these three treatments were higher than other treatments, which were $122.46,123.33$, and $124.17 \mu \mathrm{m}$ respectively. This seemed to occur because of the effect of the biggest size of $\mathrm{C1A}$ particles, which might be an undesirable option because exceeding the limits of 37 Iraqi specification, which allows maximally for $5 \%$ of the particles to stay over sieve $355 \mu \mathrm{m}$. The highest fine flour, Pass $132 \mu \mathrm{m}$, and lowest geometric mean diameter, 109.76, were found with the Control option, this result might be explained in this way: the particles of C1A, DIV which moved to the product line is consist of finer particles which are stacked together and should be separated later in the next stage of grinding inside the subsequent roller mill, this is the reason why we found the fewer particles $56.05 \mathrm{gm}, 55.65 \mathrm{gm}$ which pass through $132 \mu \mathrm{m}$ with T3 and T5. Although the results of the particles that pass through $355 \mu \mathrm{m}$ were different between the treatments, it was not as important as the particles over $355 \mu \mathrm{m}$ because the limit of the Iraqi specification that mentioned above.

Although the results of the extraction rate in the experiment were not different significantly, generally the data refers to an increase with all the treatments after Control flour (Table 2). The effect of shortening the milling path of C1A, DIV, and adding the fine bran to the product line might be not quite clear statistically, but probably it would be more clear and widely significant if the experiment lasted more hours for each treatment. According to the mill design, the long milling operation of the milling section has to take its adequate time to be settled and reach the real higher rates of flour extraction, which was very difficult to be achieved in the short time that was allowed to the researchers to complete the experiment and back to the control state of the mill. Therefore, the flour production in AL-Dorah mill is hopefully expected to grow up. Furthermore, the results of this study indicate that there is a clear effect of adding C1A and DIV on the flour moisture content, these results attributed to the fact that changing the directions of the ground materials from long routes to shorter ones will avoid extra pressure in the next roller mill (the original design) and keep away from more heat which the particles might catch during it moving between the opposite rolls. Thus, the flour particles will retain its wetness and consequently save their weight and increase the profit (Table 2).

The lower the falling number, the higher the $\alpha$ amylase activity, and the high level of $\alpha$-amylase leads to reduce baking quality. Flour with a falling number less than $250 \mathrm{~s}$ is considered a high $\alpha$ amylase activity (Ral et al., 2016). The alphaamylase activity of control flour was lower than other produced flour, however, it was significantly lower only with $\mathrm{T} 2$ and $\mathrm{T} 5$. The significant increment of $\alpha$-amylase of T5 could be due to a high amount of bran. Rani et al. (2001) mentioned that $\alpha$ amylase is more concentrated in the bran than in the endosperm. However, Alhendi et al. (2019) reported that most of the Iraqi wheat varieties had low $\alpha$ amylase activity. settled and reach the real higher rates of flour extraction, which was very difficult to be achieved in the short time that was allowed to the researchers to complete the experiment and back to the control state of the mill. Therefore, the flour production in AL-Dorah mill is hopefully expected to grow up. Furthermore, the results of this study indicate that there is a clear effect of adding C1A and DIV on the flour moisture content, these results attributed to the fact that changing the directions of the ground materials from long routes to shorter ones will avoid extra pressure in the next roller mill (the original design) and keep away from more heat which the particles might catch during it moving between the opposite rolls. Thus, the flour particles will retain its wetness and consequently save their weight and increase the profit (Table 2). 
Table 1. Particle size distribution

\begin{tabular}{ccccccccc}
\hline Treatments & $\begin{array}{c}\text { Above } \\
500 \mu \mathrm{m}, \\
\mathrm{gm}\end{array}$ & $\begin{array}{c}\text { Above } \\
355 \mu \mathrm{m}, \\
\mathrm{gm}\end{array}$ & $\begin{array}{c}\text { Above } \\
250 \mu \mathrm{m}, \\
\mathrm{gm}\end{array}$ & $\begin{array}{c}\text { Above } \\
180 \mu \mathrm{m}, \mathrm{gm}\end{array}$ & $\begin{array}{c}\text { Above } \\
132 \mu \mathrm{m}, \\
\mathrm{gm}\end{array}$ & $\begin{array}{c}\text { Pass } \\
132 \mu \mathrm{m}, \mathrm{gm}\end{array}$ & $\mathrm{d}_{\mathrm{gw}}$ & $\mathrm{S}_{\mathrm{gw}}$ \\
\hline Control & $0.35+0.07^{\mathrm{d}}$ & $1.00 \pm 0.14^{\mathrm{d}}$ & $2.75 \pm 0.07^{\mathrm{e}}$ & $10.50 \pm 0.57^{\mathrm{b}}$ & $21.20 \pm 0.42^{\mathrm{a}}$ & $65.85 \pm 0.21^{\mathrm{a}}$ & 109.76 & 1.37 \\
$\mathrm{~T} 1$ & $4.10 \pm 0.57^{\mathrm{a}}$ & $3.10 \pm 0.00^{\mathrm{a}}$ & $4.70 \pm 0.28^{\mathrm{c}}$ & $10.30 \pm 0.14^{\mathrm{cb}}$ & $18.65 \pm 0.07^{\mathrm{c}}$ & $57.75 \pm 0.07^{\mathrm{d}}$ & 122.46 & 1.59 \\
$\mathrm{~T} 2$ & $0.65 \pm 0.07^{\mathrm{d}}$ & $1.45 \pm 0.07^{\mathrm{c}}$ & $3.60 \pm 0.00^{\mathrm{d}}$ & $11.50 \pm 0.28^{\mathrm{a}}$ & $20.30 \pm 0.28^{\mathrm{b}}$ & $60.35 \pm 0.50^{\mathrm{c}}$ & 113.30 & 1.41 \\
$\mathrm{~T} 3$ & $3.45 \pm 007^{\mathrm{b}}$ & $3.15 \pm 0.07^{\mathrm{a}}$ & $5.85 \pm 0.35^{\mathrm{b}}$ & $10.95 \pm 0.21^{\mathrm{ba}}$ & $18.00 \pm 0.14^{\mathrm{c}}$ & $56.05 \pm 0.21^{\mathrm{e}}$ & 123.33 & 1.10 \\
$\mathrm{~T} 4$ & $1.35 \pm 0.07^{\mathrm{c}}$ & $1.45 \pm 0.21^{\mathrm{d}}$ & $3.35 \pm 0.07^{\mathrm{d}}$ & $9.70 \pm 0.00^{\mathrm{c}}$ & $21.60 \pm 0.28^{\mathrm{a}}$ & $61.10 \pm 0.14^{\mathrm{b}}$ & 112.95 & 1.43 \\
$\mathrm{~T} 5$ & $4.25 \pm 0.07^{\mathrm{a}}$ & $2.30 \pm 0.00^{\mathrm{b}}$ & $6.80 \pm 0.00^{\mathrm{a}}$ & $9.70 \pm 0.14^{\mathrm{c}}$ & $19.90 \pm 0.42^{\mathrm{b}}$ & $55.65 \pm 0.07^{\mathrm{e}}$ & 124.17 & 1.59
\end{tabular}

Values are expressed as a mean. Means with different letters within the same column are significantly different at $\mathrm{P}<0.05$.

$\mathrm{d}_{\mathrm{gw}}$ - The geometric mean diameter, $\mathrm{S}_{\mathrm{gw}}$ - the geometric standard deviation.

Table 2. Flour characteristics

\begin{tabular}{cccccccc}
\hline Treatments & $\begin{array}{c}\text { Extraction } \\
\text { rate }\end{array}$ & $\begin{array}{c}\text { Moisture, } \\
\%\end{array}$ & $\begin{array}{c}\text { Falling } \\
\text { number, } \mathrm{s}\end{array}$ & $\begin{array}{c}\text { Ash db, } \\
\%\end{array}$ & $\begin{array}{c}\text { Protein db } \\
12 \% w b, \%\end{array}$ & $\begin{array}{c}\text { Gluten db, } \\
\%\end{array}$ & $\begin{array}{c}\text { Gluten } \\
\text { index, } \%\end{array}$ \\
\hline Control & $77.85 \pm 0.35^{\mathrm{a}}$ & $11.55 \pm 0.2^{\mathrm{d}}$ & $523 \pm 46.7^{\mathrm{a}}$ & $1.005 \pm 0.015^{\mathrm{c}}$ & $12.06 \pm 0.05^{\mathrm{c}}$ & $31.7 \pm 0.48^{\mathrm{b}}$ & $86.4 \pm 5.5^{\mathrm{ab}}$ \\
T1 & $77.95 \pm 1.77^{\mathrm{a}}$ & $11.78 \pm 0.07^{\mathrm{ab}}$ & $473 \pm 2.1^{\mathrm{ab}}$ & $1.015 \pm 0.008^{\mathrm{c}}$ & $12.07 \pm 0.04^{\mathrm{c}}$ & $32.3 \pm 0.61^{\mathrm{ab}}$ & $85.2 \pm 4.9^{\mathrm{ab}}$ \\
T2 & $78.05 \pm 0.21^{\mathrm{a}}$ & $11.73 \pm 0.14^{\mathrm{b}}$ & $437 \pm 28.3^{\mathrm{b}}$ & $1.003 \pm 0.008^{\mathrm{c}}$ & $12.07 \pm 0.03^{\mathrm{c}}$ & $33.0 \pm 0.58^{\mathrm{a}}$ & $75.2 \pm 1.0^{\mathrm{b}}$ \\
T3 & $78.55 \pm 0.64^{\mathrm{a}}$ & $11.83 \pm 0.42^{\mathrm{a}}$ & $449 \pm 58.0^{\mathrm{ab}}$ & $1.025 \pm 0.008^{\mathrm{cb}}$ & $12.11 \pm 0.08^{\mathrm{bc}}$ & $35.1 \pm 0.01^{\mathrm{ab}}$ & $96.3 \pm 0.4^{\mathrm{a}}$ \\
T4 & $79.15 \pm 0.49^{\mathrm{a}}$ & $11.65 \pm 0.14^{\mathrm{c}}$ & $476 \pm 2.1^{\mathrm{ab}}$ & $1.121 \pm 0.000^{\mathrm{a}}$ & $12.23 \pm 0.00^{\mathrm{a}}$ & $33.3 \pm 2.91^{\mathrm{ab}}$ & $83.7 \pm 11.9^{\mathrm{ab}}$ \\
T5 & $79.65 \pm 0.07^{\mathrm{a}}$ & $11.80 \pm 0.07^{\mathrm{a}}$ & $440 \pm 21.2^{\mathrm{b}}$ & $1.077 \pm 0.065^{\mathrm{ab}}$ & $12.19 \pm 0.05^{\mathrm{ab}}$ & $33.1 \pm 0.13^{\mathrm{ab}}$ & $92.1 \pm 7.9^{\mathrm{a}}$
\end{tabular}

Values are expressed as a mean. Means with different letters within the same column are significantly different at $\mathrm{P}<0.05$. db, dry basis

The lower the falling number, the higher the $\alpha$ amylase activity, and the high level of $\alpha$-amylase leads to reduce baking quality. Flour with a falling number less than 250 s is considered a high $\alpha$ amylase activity (Ral et al. 2016). The alphaamylase activity of control flour was lower than other produced flour, however, it was significantly lower only with $\mathrm{T} 2$ and $\mathrm{T} 5$. The significant increment of $\alpha$-amylase of T5 could be due to a high amount of bran. Rani et al. (2001) mentioned that $\alpha$ amylase is more concentrated in the bran than in the endosperm. However, Alhendi et al. (2019) reported that most of the Iraqi wheat varieties had low $\alpha$ amylase activity.

The highest ash content was recorded firstly with $\mathrm{T} 4$ and followed by T5 (in case of adding fine bran). 
This observed correlation might be interrupted in this way: the ash content quantity in the wheat kernel increases from the endosperm to the external layers, which have more ash content than the core (Fišteš and Vukmirović 2009), another relation between the ash content and the flour extraction rate could be noted in Table 2, the more kernel skin ingredients, the more contamination (ash) will be in the end-product (Sakhare and Inamdar 2014). These results seem to be consistent with the suggestions of Azizi et al. (2006) who mentioned in his study that flour ash content is increased with increasing the flour extraction rate, as it was increased from $0.54 \%$ to $1.51 \%$ for the produced flour with $70 \%$ and $93 \%$ extraction rate respectfully.

Although the 37 Iraqi limitations allowed the ash content in the flour (produced under the control of Iraqi ministry of trade laboratories), not to go over $1 \%$, the Iraqis mills prefer to produce flour with less amount of ash and far from $1 \%$. Hence, the flour produced in $\mathrm{T} 1, \mathrm{~T} 2$ is considerably preferable since the ash content of its flour is closer to the ash content in Control flour.

This study showed an important evidence for the influence of the fine bran on the protein content in flour, the possible reason for that is the protein cells are located generally in the sub-aleurone area of wheat endosperm; which will be higher than the amount of protein content in the central endosperm regions, as a result, the higher the bran particles, the more protein content in the flour (Edwards et al. 2007). On the other hand, the gluten result attributed to the fact that the gluten content in the endosperm cells is higher compared with the outer cells of the wheat kernel. This fact is supported by the results of the highest percentage of gluten content $(30.143 \%)$ with T2 whose particles are the nearest to the center.

The mill pipes changes and adding FB seems has no effect on the gluten index. The gluten index of the control flour was mostly not significantly different on the other produced flour. However, there was an unexpected reduction of the gluten index for $\mathrm{T} 2$ flour.

The current study found that the highest water absorption $67.0 \%, 66.75 \%$, were recorded with the biggest ratio of bran $\mathrm{T} 4$ and $\mathrm{T} 5$ respectively. In addition, and generally, farinograph water absorption was raised in the case of mixing the flour with fiber fractions. This is a predictable result since fibers characteristically bind more water compared with the other flour components: starch and protein (Lineback and Rasper 1988). The fact is decreasing the size of the particles leads to a decrease in the ability to captivating water molecules. On the other hand, increasing the protein content is often affects positively the water absorption (Popper et al. 2006), this fact agrees with the T4, T5 has the highest water absorption (Table 3). A possible explanation is that water absorption as defined by the farinograph technique is the consequent of the whole dough system and it appears to be determined by the properties of fine bran particles added with T4, T5. Additionally, Azizi et al. (2006) reported that the bigger particle size of bran influences the flour properties more than the influence of the finer particle size, which can involve gluten network, texture, structuring, and bread quality.

From the results in Table 3, it is clear that the lowest stability time was present with the treatments $\mathrm{T} 1$ and T5, where the high size of particles was found (Table 1). The reason might be referred to as the harmful physical effect of the big particles on the gluten net, which reduces the strength of the gluten aggregation and prevent the molecules to create a firm connection and later to keep the gas inside. The data of this study also refers to the effect of increasing the extraction rate by adding the bigger particles (T1) on the stability time. This result goes along with the data achieved by Azizi et al. (2006) that in their study they mentioned that dough stability was affected negatively with a high extraction rate. On the other hand, Ramírez-Wong et al. (2007) explained that dough stability was decreased when increasing the extraction rate from $70 \%$ to $80 \%$.

Besides, the gluten quantity in the wheat grain is a decisive factor to define the time to get a stabilized dough, while the quality of the gluten in the flour so far determines the time needed for netting the gluten molecules and bond them together suitably (Popper et al., 2006). Likewise, the physical effect of the sharp edges of the bran particles might tear the gluten net down and force the dough to take more time for developing.

The extensogram characteristics of dough produced from different treatments shown in Table 4. Energy and dough strength of the control flour were mostly higher than other treatments, however, it was only higher significantly than $\mathrm{T} 4$ and $\mathrm{T} 5$ flours for 45 min resting time and for $\mathrm{T} 2$ for $135 \mathrm{~min}$ resting time. 
Table 3. Farinograph

\begin{tabular}{ccccccc}
\hline Treatments & $\begin{array}{c}\text { Water } \\
\text { absorption, } \%\end{array}$ & $\begin{array}{c}\text { Stability, } \\
\text { min }\end{array}$ & $\begin{array}{c}\text { Development } \\
\text { time, } \min \end{array}$ & $\begin{array}{c}\text { Dos*, BU } \\
10 \mathrm{~min}\end{array}$ & $\begin{array}{c}\text { Dos*, BU } \\
12 \mathrm{~min}\end{array}$ & Q number \\
\hline Control & $66.0 \pm 0.0^{\mathrm{b}}$ & $5.4 \pm 0.3^{\mathrm{a}}$ & $5.7 \pm 0.0^{\mathrm{ba}}$ & $45.0 \pm 0.0^{\mathrm{a}}$ & $74.0 \pm 2.8^{\mathrm{a}}$ & $78.5 \pm 2.1^{\mathrm{bc}}$ \\
T1 & $65.3 \pm 0.4^{\mathrm{c}}$ & $4.6 \pm 0.7^{\mathrm{b}}$ & $5.7 \pm 0.0^{\text {ba }}$ & $48.0 \pm 7.1^{\mathrm{a}}$ & $80.5 \pm 2.1^{\mathrm{a}}$ & $77.0 \pm 2.8^{\mathrm{c}}$ \\
T2 & $66.0 \pm 0.0^{\mathrm{b}}$ & $5.3 \pm 0.6^{\mathrm{a}}$ & $5.9 \pm 0.1^{\mathrm{a}}$ & $40.5 \pm 0.7^{\mathrm{a}}$ & $68.5 \pm 6.3^{\mathrm{a}}$ & $85.5 \pm 0.7^{\mathrm{a}}$ \\
T3 & $66.0 \pm 0.0^{\mathrm{b}}$ & $5.1 \pm 0.3^{\mathrm{a}}$ & $5.9 \pm 0.1^{\mathrm{a}}$ & $39.5 \pm 0.7^{\mathrm{a}}$ & $67.0 \pm 5.7^{\mathrm{a}}$ & $83.5 \pm 0.7^{\mathrm{ab}}$ \\
T4 & $67.0 \pm 0.0^{\mathrm{a}}$ & $5.4 \pm 0.3^{\mathrm{a}}$ & $5.4 \pm 0.2^{\mathrm{b}}$ & $44.5 \pm 0.7^{\mathrm{a}}$ & $71.5 \pm 7.8^{\mathrm{a}}$ & $79.0 \pm 1.4^{\mathrm{b}}$ \\
T5 & $66.8 \pm 0.1^{\mathrm{a}}$ & $5.0 \pm 0.0^{\text {ba }}$ & $5.5 \pm 0.3^{\text {ba }}$ & $43.5 \pm 4.9^{\mathrm{a}}$ & $76.5 \pm 6.4^{\mathrm{a}}$ & $82.0 \pm 4.2^{\mathrm{abc}}$ \\
\hline
\end{tabular}

Values are expressed as a mean. Means with different letters within the same column are significantly different at $\mathrm{P}$ $<0.05$. Dos: degree of softenning; Q number: farinograph quality number.

Table 4. Extensograph

\begin{tabular}{|c|c|c|c|c|c|c|}
\hline Treatments & Time (min) & Energy, $\mathrm{cm}^{2}$ & $\begin{array}{l}\text { Extensibility, } \\
\mathrm{mm}\end{array}$ & $\begin{array}{c}\text { Resistance, } \\
\text { BU }\end{array}$ & $\begin{array}{c}\text { Max resistance, } \\
\text { BU }\end{array}$ & $\begin{array}{l}\text { Ratio R/E, } \\
\max \end{array}$ \\
\hline \multirow{3}{*}{ Control } & 45 & $63.0 \pm 1.4^{a}$ & $182.0 \pm 1.4^{\mathrm{a}}$ & $216.5 \pm 16.3^{a}$ & $259.0 \pm 7.1^{\mathrm{a}}$ & $1.4 \pm 0.0^{\mathrm{a}}$ \\
\hline & 90 & $65.5 \pm 3.5^{\mathrm{a}}$ & $192.0 \pm 22.6^{\mathrm{a}}$ & $237.5 \pm 13.4^{a}$ & $284.0 \pm 19.8^{\mathrm{a}}$ & $1.5 \pm 0.1^{\mathrm{a}}$ \\
\hline & 135 & $79.5 \pm 2.1^{\mathrm{a}}$ & $163.5 \pm 3.5^{\mathrm{a}}$ & $265.0 \pm 1.4^{\mathrm{a}}$ & $309.0 \pm 5.7^{\mathrm{a}}$ & $1.9 \pm 0.0^{\mathrm{a}}$ \\
\hline \multirow{3}{*}{$\mathrm{T} 1$} & 45 & $59.0 \pm 7.1^{\mathrm{ba}}$ & $209.5 \pm 12.0^{\mathrm{a}}$ & $201.5 \pm 27.6^{\mathrm{ab}}$ & $236.0 \pm 24.0^{\mathrm{ab}}$ & $1.2 \pm 0.1^{\mathrm{ab}}$ \\
\hline & 90 & $68.5 \pm 4.9^{a}$ & $182.5 \pm 13.4^{a}$ & $242.5 \pm 3.5^{\mathrm{a}}$ & $280.5 \pm 16.3^{\mathrm{ab}}$ & $1.6 \pm 0.1^{\mathrm{a}}$ \\
\hline & 135 & $60.5 \pm 4.9^{\mathrm{ab}}$ & $192.5 \pm 7.8^{\mathrm{a}}$ & $222.0 \pm 14.1^{\mathrm{a}}$ & $265.0 \pm 8.5^{\mathrm{b}}$ & $1.4 \pm 0.1^{\mathrm{ab}}$ \\
\hline \multirow{3}{*}{$\mathrm{T} 2$} & 45 & $59.0 \pm 1.4^{\mathrm{ab}}$ & $212.0 \pm 9.9^{\mathrm{a}}$ & $181.0 \pm 5.7^{\mathrm{b}}$ & $227.0 \pm 1.4^{\mathrm{bc}}$ & $1.1 \pm 0.1^{\mathrm{b}}$ \\
\hline & 90 & $57.5 \pm 14.8^{\mathrm{a}}$ & $175.0 \pm 24.0^{\mathrm{a}}$ & $195.5 \pm 16.3^{b}$ & $238.0 \pm 33.9^{\mathrm{cb}}$ & $1.4 \pm 0.0^{\mathrm{a}}$ \\
\hline & 135 & $52.0 \pm 11.3^{b}$ & $162.0 \pm 15.6^{\mathrm{a}}$ & $221.0 \pm 32.5^{\mathrm{a}}$ & $251.5 \pm 33.2^{\mathrm{b}}$ & $1.6 \pm 0.1^{\mathrm{ab}}$ \\
\hline \multirow{3}{*}{$\mathrm{T} 3$} & 45 & $57.5 \pm 2.1^{\mathrm{ba}}$ & $180.0 \pm 19.8^{a}$ & $203.0 \pm 1.4^{\mathrm{ab}}$ & $234.0 \pm 4.2^{\mathrm{ab}}$ & $1.3 \pm 0.1^{\mathrm{ab}}$ \\
\hline & 90 & $55.0 \pm 2.8^{\mathrm{a}}$ & $208.0 \pm 49.5^{\mathrm{a}}$ & $202.5 \pm 9.2^{\mathrm{a}}$ & $234.0 \pm 5.7^{\mathrm{c}}$ & $1.2 \pm 0.4^{\mathrm{a}}$ \\
\hline & 135 & $63.5 \pm 7.8^{\mathrm{ab}}$ & $217.0 \pm 59.4^{\mathrm{a}}$ & $233.5 \pm 34.6^{\mathrm{a}}$ & $275.0 \pm 9.9^{\mathrm{ab}}$ & $1.3 \pm 0.4^{b}$ \\
\hline \multirow{3}{*}{$\mathrm{T} 4$} & 45 & $47.0 \pm 1.4^{\mathrm{c}}$ & $178.0 \pm 26.9^{\mathrm{a}}$ & $177.0 \pm 0.0^{\mathrm{b}}$ & $208.0 \pm 4.2^{\mathrm{c}}$ & $1.2 \pm 0.2^{\mathrm{a}}$ \\
\hline & 90 & $57.5 \pm 3.5^{\mathrm{a}}$ & $180.0 \pm 4.2^{\mathrm{a}}$ & $220.0 \pm 12.7^{\mathrm{ab}}$ & $253.0 \pm 8.5^{\mathrm{abc}}$ & $1.4 \pm 0.0^{\mathrm{a}}$ \\
\hline & 135 & $66.0 \pm 2.8^{\mathrm{a}}$ & $183.5 \pm 29.0^{\mathrm{a}}$ & $244.0 \pm 11.3^{\mathrm{a}}$ & $285.5 \pm 7.8^{\mathrm{ab}}$ & $1.6 \pm 0.3^{\mathrm{ab}}$ \\
\hline \multirow{3}{*}{ T5 } & 45 & $55.0 \pm 0.0^{\mathrm{b}}$ & $178.0 \pm 1.4^{\mathrm{a}}$ & $201.0 \pm 7.1^{\mathrm{ab}}$ & $231.0 \pm 1.4^{\mathrm{bc}}$ & $1.3 \pm 0.1^{\mathrm{ab}}$ \\
\hline & 90 & $60.0 \pm 1.4^{\mathrm{a}}$ & $168.0 \pm 24.0^{\mathrm{a}}$ & $240.5 \pm 6.4^{\mathrm{a}}$ & $267.0 \pm 2.8^{\mathrm{abc}}$ & $1.6 \pm 0.3^{\mathrm{a}}$ \\
\hline & 135 & $58.5 \pm 6.4^{a}$ & $172.5 \pm 34.6^{a}$ & $238.0 \pm 5.7^{\mathrm{a}}$ & $267.5 \pm 6.4^{\mathrm{b}}$ & $1.6 \pm 0.3^{\mathrm{ab}}$ \\
\hline
\end{tabular}

Values are expressed as a mean. Means with different letters within the same column are significantly different at $\mathrm{P}<0.05$.

The energy values of this study agree with the energy values reported by Alhendi et al. (In press) that done on flour produced by an industry mill by using mixed wheat also, while in both studies the energy values were less than the energy values reported by Hassan et al. (2015) and Mohammed et al. (2012), which were $\left(115,116\right.$, and $\left.106 \mathrm{~cm}^{2}\right)$ and $\left(170,145\right.$, and $\left.135 \mathrm{~cm}^{2}\right)$ respectively for the same resting times. On the other hand, Flour extensibility of all the treatments was different insignificantly, while dough resistance of control flour was higher than some treatments (Table 4), which refers to the stronger dough too. The reason behind that flour control stronger than others is probably the bigger particle size of the flour and subsequently the moisture content. Azizi et al. (2006) reported that the coarser particle size of bran influences the flour quality more than the finer particle size, which can affect gluten network, texture, and general quality of bread. Also, Ramírez-Wong et al. (2007) mentioned that dough strength is known to be reduced with increasing extraction rate, probably because of impaired network formation of gluten as a result of big particle size. 


\section{Conclusions}

The purpose of the present study was to evaluate $\mathrm{Al}$ Dorah flour properties after making a few changes in the milling section design. To determine the possibility of applying best-suggested treatments in the experiment and adopt it as a new work style in the milling section for other mills in Iraq to further improve its production lines.

1. This study demonstrated that Al Dorah mill could produce flour with a new change to get a promising increase of flour extraction rate and keep the flour moisture content, which raises the profits and eases the milling process.

2. The flour properties with $\mathrm{T} 1, \mathrm{~T} 2$, and $\mathrm{T} 3$ recorded several values not significantly different from the Control flour, (in some cases better than Control flour) in terms of Falling number, Ash, Protein, and gluten.

3. The test confirmed that the dough properties were not affected negatively with all the treatments in the experiment, owing to the constant gluten content in all the flours of the study, besides, the impact of adding fine bran on dough specification was less than the effect of adding particles $>132 \mu \mathrm{m}$ and $<280 \mu \mathrm{m}$.

\section{Acknowledgments}

The authors are grateful to the State Company for Grain Processing for allowing us to use a governmental mill and made all the required adjustments.

\section{References}

AACC Methods. Approved methods of the American Association of Cereal Chemists, 10th edition, American Association of Cereal Chemists, St. Paul, MN, USA, 2000. http://methods.aaccnet.org/search.aspx

Al-Dmoor, H.M. Cake flour: functionality and quality. European Scientific Journal, ESJ, 2013, 9(3): 166180.

Alhendi, A.S., Ahmed, T.H., Albayati, W.S., Almukhtar, B.Q., Ali. Z.K., and Al-Hayani, N.K. Comparisons between flour quality produced from three different mills: buhler, quadrumat, and industry mills. International Journal of Food Studies, (In press).

Alhendi, A.S., Almukhtar, B.Q., and Al-haddad, F.M. Changes in flour quality of four iraqi wheat varieties during storage. Pertanika Journal of Tropical Agricultural Science, 2019, 42 (1): 15 - 25.
Anjum, F.M., Khan, M.R., Din, A., Saeed, M., Pasha, I. and Arshad, M.U. Wheat gluten: high molecular weight glutenin subunits - structure, genetics, and relation to dough elasticity. Journal of Food Science, 2007, 72(3): 56-63. https://doi.org/10.1111/j.1750-3841.2007.00292.x

Azizi, M.H., SEYEDIN, S., and Peyghambardoust, S.H. Effect of flour extraction rate on flour composition, dough rheological characteristics and quality of flatbread. Journal of Agricultural Science and Technology, 2006, 8, 323-330.

Edwards, M.A., Osborne, B.G. and Henry, R.J. Investigation of the Effect of Conditioning on the Fracture of Hard and Soft Wheat Grain by the Single-Kernel Characterization System: A Comparison with Roller Milling. Journal of Cereal Science, 2007, 46(1): 64-74. https://doi.org/10.1016/j.jcs.2006.12.001

Faměra, O., Hrušková, M. and Novotna, D. Evaluation of Methods for Wheat Grain Hardness Determination. Plant, Soil and Environment, 2004, 50: 489-493.

Fišteš, A.Z. and Vukmirović, Đ.M. Reduction of Wheat Middlings Using a Conventional and Eight-Roller Milling Systems. Acta Periodica Technologica, 2009, 40: 25-34. https://doi.org/10.2298/APT0940025F

Hareland, G.A. Evaluation of flour particle size distribution by laser diffraction, sieve analysis and near-infrared reflectance spectroscopy. Journal of Cereal Science, 1994, 20(2):183-190. https://doi.org/10.1006/jcrs.1994.1058

Joye, I.J., Lagrain, B. and Delcour, J.A. Endogenous Redox Agents and Enzymes that Affect Protein Network Formation During Bread Making-A review. Journal of Cereal Science, 2009, 50(1): 110. https://doi.org/10.1016/j.jcs.2009.04.002

Krasileva, K.V., Vasquez-Gross, H.A., Howell, T., Bailey, P., Paraiso, F., Clissold, L., Simmonds, J., Ramirez-Gonzalez, R.H., Wang, X., Borrill, P. and Fosker, C. Uncovering Hidden Variation in Polyploid Wheat. Proceedings of the National Academy of Sciences, 2017, 114(6): 913-921. https://doi.org/10.1073/pnas.1619268114

Lineback, D.R., Rasper, V.F. Wheat carbohydrates. In: Pomeranz, Y. (Ed.) Wheat: Chemistry and Technology, third ed, vol. 1. AACC, St Paul, 1988, 277-372.

Popper, L., Schäfer, W. and Freund, W. Future of flour: A compendium of flour improvement, 2006, Agrimedia.

Ral, J.P., Whan, A., Larroque, O., Leyne, E., Pritchard, J., Dielen, A.S., Newberry, M. Engineering high $\alpha$ amylase levels in wheat grain lowers Falling Number but improves baking properties. Plant 
Biotechnology Journal, 2016,14(1): 364-376.

https://doi.org/10.1111/pbi.12390

Ramírez- Wong,B., Walker, C.E., Ledesma- Osuna, A.I., Torres, P. I., Medina- Rodríguez, C.L., López- Ahumada, G.A., Salazar-Garcia, M.G., Ortega-Ramirez, R., Jonson, A.M., \& Flores, R. A. Effect of flour extraction rate on white and red winter wheat flour compositions and tortilla texture. Cereal chemistry, 2007, 84(3): 207-213. https://doi.org/10.1094/CCHEM-84-3-0207

Rani, K.U., Prasada Rao U.J.S., Leelavathi K., and Haridas Rao, P. Distribution of enzymes in wheat flour mill streams. Journal of Cereal Science, 2001, 34(3): 233-242 https://doi.org/10.1006/jcrs.2000.0393

Sakhare, S.D. and Inamdar, A.A. The Cumulative Ash Curve: A Best Tool to Evaluate Complete Mill Performance. Journal of Food Science and Technology, 2014, 51(4): 795-799. https://doi.org/10.1007/s13197-011-0549-z

Sonaye, S.Y. and Baxi, R.N. Particle Size Measurement and Analysis of flour. International Journal of Engineering Research and Applications, 2012, 2(3): 1839-1824.

Steglich, T., Bernin, D., Moldin, A., Topgaard, D. and Langton, M. Bran Particle Size Influence on Pasta Microstructure, Water Distribution, and Sensory Properties. Cereal Chemistry, 2015, 92(6): 617-623. https://doi.org/10.1094/CCHEM-03-15-0038-R

Wang, N., Hou, G.G., Kweon, M. and Lee, B. Effects of Particle Size on the Properties of Whole-Grain Soft Wheat Flour and Its Cracker Baking Performance. Journal of Cereal Science, 2016, 69: 187-193. http://dx.doi.org/10.1016/j.jcs.2016.03.010

Wieser, H., Koehler, P. and Konitzer, K. Celiac Disease and Gluten: Multidisciplinary Challenges and Opportunities (1st ed.), Academic Press Elsevier, London, Waltham, San Diego, 2014, 53-75.

Wilcox, R. A., Deyoe, C. W., \& Pfost, H. B. A method for determining and expressing the size of feed particles by sieving. Poultry Science, 1970, 49(1), 913. https://doi.org/10.3382/ps.0490009 